Hiroshi Mitsuyasu $\cdot$ Hidetoshi Ozawa $\cdot$ Yasuhiko Takeda Yasuyuki Fukumaki

\title{
Novel polymorphisms in the upstream region of the human dopamine D4 receptor (DRD4) gene
}

\begin{abstract}
We found nine novel polymorphisms in the upstream region of the human dopamine $\mathrm{D} 4$ receptor (DRD4) gene of Japanese by direct sequencing. These polymorphisms are $-809 \mathrm{G}>\mathrm{A},-768 \mathrm{G}>\mathrm{A},-616 \mathrm{C}>\mathrm{G},-603 \mathrm{~T}$ $>$ del, $-602 \mathrm{G}>\mathrm{del},-600 \mathrm{G}>\mathrm{C},-376 \mathrm{C}>\mathrm{T},-291 \mathrm{C}>\mathrm{T}$, and $-128 \mathrm{G}>\mathrm{T}$. One known polymorphism, $-521 \mathrm{C}>\mathrm{T}$, was also recognized. Six of these sites were identified as restriction fragment length polymorphisms (RFLPs).
\end{abstract}

Key words Dopamine D4 receptor gene $\cdot$ Promoter · Polymorphisms $\cdot$ RFLP

\section{Introduction}

The human dopamine D4 receptor (DRD4) is of great interest in molecular studies of human personality and psychiatric disorders such as schizophrenia, mood disorders, attention deficit hyperactivity disorder, Tourette's syndrome, alcoholism, and substance abuse.

The density of DRD4 was found to be six-fold elevated in the brains of schizophrenic patients (Seeman et al. 1993). DRD4 mRNA was elevated in the frontal cortex of schizophrenics in postmortem studies compared with controls (Stefanis et al. 1998), suggesting that there are allelic variations in transcription levels of the $D R D 4$ gene.

Our previous study of $D R D 4$ gene transcription revealed that the region between -591 and -123 relative to the first nucleotide of the initiation codon contained the promoter of the DRD4 gene, which is responsible for the cell typespecific expression of the gene, while the negative modulator was located between -770 and -679 (Kamakura et al. 1997). Based on these results we tried to detect polymorphisms in the upstream region of the DRD4 gene spanning

H. Mitsuyasu $\cdot$ H. Ozawa $\cdot$ Y. Takeda $\cdot$ Y. Fukumaki $(\triangle)$ Division of Disease Genes, Institute of Genetic Information, Kyushu University, 3-1-1 Maidashi, Higashi-ku, Fukuoka 812-8582, Japan

Tel. +81-92-642-6167; Fax +81-92-632-2375

e-mail: yfukumak@gen.kyushu-u.ac.jp the negative modulator and the cell type-specific promoter region.

\section{Source and description}

DNA samples

Ten-ml venous blood samples were drawn from unrelated Japanese individuals into heparin-containing tubes. Genomic DNA was extracted by a rapid non-enzymatic method. Leukocyte DNA was salted out with saturated $\mathrm{NaCl}$ solution (Lahiri and Nurnberger 1991).

PCR primers

Two sets of primers were used to amplify the upstream region (regions A and B) of the DRD4 gene (Fig. 1). Region A was amplified by polymerase chain reaction (PCR), using the sense primer, D4pos3 (5'-CTCAGGTCTTTCTGCGTCTGGC-3', -472/-451) and the antisense primer, D4pos4 (5'-GGCTCACCTCGGAGTAGACGAA-3', +292/+271). Region B was amplified by PCR using the sense primer, D4neg3 (5'-CAGGTCACAGGTCACCCCTCTT-3', -947/ -926) and the antisense primer, D4neg4 (5'-TTGCTCATCTTGGAATTTTGCG-3', $-156 /-177)$. The sense primer, D4pos1 (5'-GGAGGTTTTGCCAGATACCA-3', -434/ $-415)$ was used to determine the nucleotide sequence of region A.

\section{PCR conditions}

The first PCR to amplify region A was performed in a volume of $20 \mu \mathrm{l}$ containing $60 \mathrm{ng}$ genomic DNA, $4 \mathrm{pmol}$ of each primer (D4pos3, D4pos4), $10 \mathrm{mM}$ Tris- $\mathrm{HCl}$ ( $\mathrm{pH} 8.3$ ), $50 \mathrm{mM} \mathrm{KCl}, 2.0 \mathrm{mM} \mathrm{MgCl} 2,200 \mu \mathrm{M}$ each of dNTPs, $7.5 \%$ dimethylsulfoxide (DMSO), and 0.5 U AmpliTaq Gold (PE Biosystems, Foster City, CA, USA). The cycle conditions were $95^{\circ} \mathrm{C}$ for $10 \mathrm{~min}$, then 40 cycles of $94.5^{\circ} \mathrm{C}$ for $20 \mathrm{~s}$, 

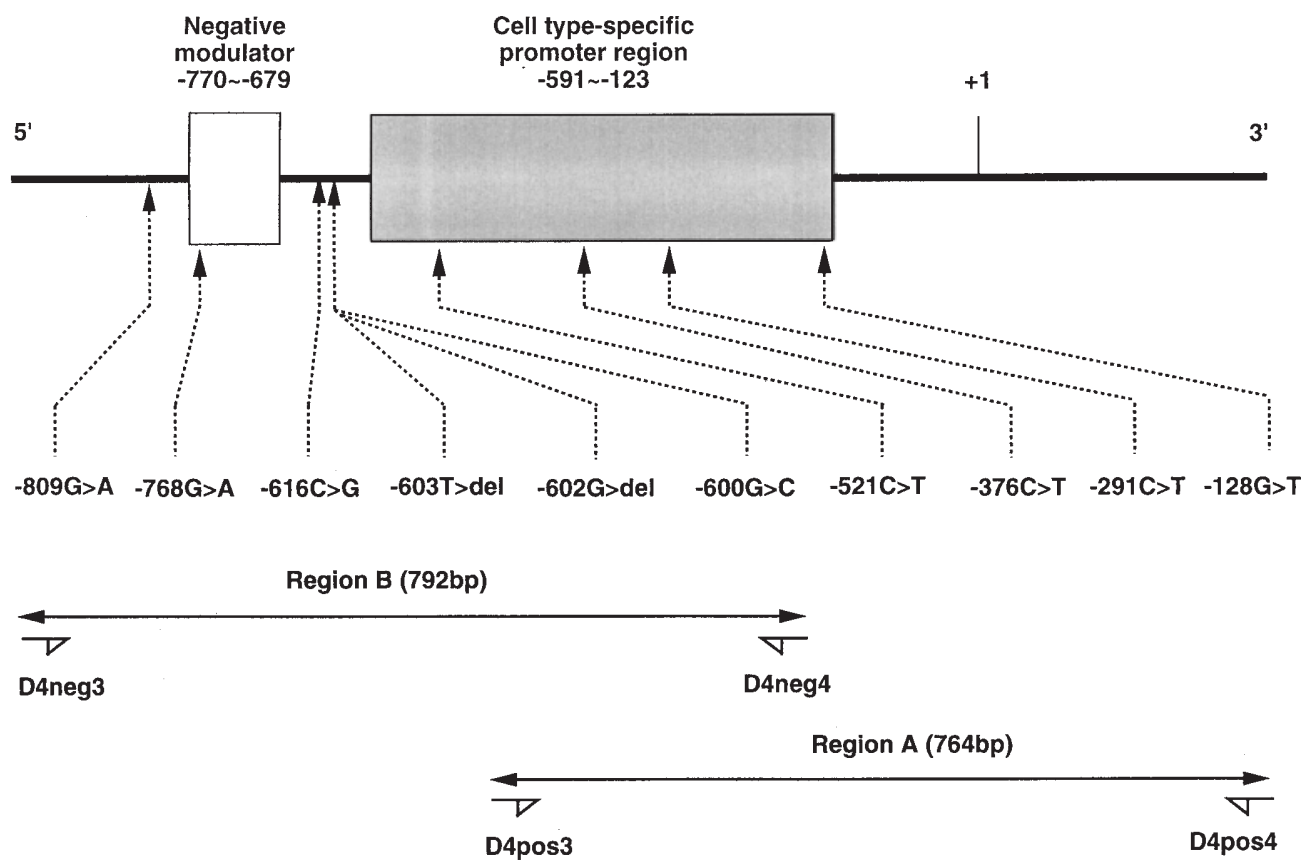

Fig. 1. Locations of ten polymorphisms in the upstream region of the human $D R D 4$ gene. Ten polymorphic sites $(-809 \mathrm{G}>\mathrm{A},-768 \mathrm{G}>\mathrm{A}$, $-616 \mathrm{C}>\mathrm{G},-603 \mathrm{~T}>\mathrm{del},-602 \mathrm{G}>\mathrm{del},-600 \mathrm{G}>\mathrm{C},-521 \mathrm{C}>\mathrm{T}$, $-376 \mathrm{C}>\mathrm{T},-291 \mathrm{C}>\mathrm{T},-128 \mathrm{G}>\mathrm{T}$ ) are covered by regions $\mathrm{A}$ and $\mathrm{B}$. Each position is shown relative to the first nucleotide of the initiation codon, indicated as +1 . The cell type-specific promoter region between -591 and -123 (gray box) contains the promoter of the DRD4 gene.

$61.0^{\circ} \mathrm{C}$ for $5 \mathrm{~s}$, and $72^{\circ} \mathrm{C}$ for $1 \mathrm{~min} 45 \mathrm{~s}$, with a final extension step of $7 \mathrm{~min}$ at $72^{\circ} \mathrm{C}$, on a Perkin Elmer 2400 Thermocycler. The second PCR was performed in a volume of $20 \mu \mathrm{l}$ containing $1.5 \mu \mathrm{l}$ of the first PCR product, $4 \mathrm{pmol}$ of each primer (D4pos3, D4pos4), $10 \mathrm{mM}$ Tris- $\mathrm{HCl}(\mathrm{pH} 8.3)$, $50 \mathrm{mM} \mathrm{KCl}, 2.0 \mathrm{mM} \mathrm{MgCl} 2,200 \mu \mathrm{M}$ each of dNTPs, $7.5 \%$ DMSO, and 0.5 U AmpliTaq Gold. The cycle conditions were as the same as those for the first PCR except that 22 cycles rather than 40 cycles were performed.

PCR to amplify region B was performed in a volume of $50 \mu \mathrm{l}$ containing $100 \mathrm{ng}$ genomic DNA, $25 \mathrm{pmol}$ of each primer, $10 \mathrm{mM}$ Tris- $\mathrm{HCl}(\mathrm{pH} 8.3), 50 \mathrm{mM} \mathrm{KCl}, 1.8 \mathrm{mM}$ $\mathrm{MgCl}_{2}, 200 \mu \mathrm{M}$ each of dNTPs, $5.0 \%$ DMSO, and $1.25 \mathrm{U}$ AmpliTáq Gold. The cycle conditions were $95^{\circ} \mathrm{C}$ for $10 \mathrm{~min}$, then 40 cycles of $95^{\circ} \mathrm{C}$ for $20 \mathrm{~s}, 57^{\circ} \mathrm{C}$ for $5 \mathrm{~s}$, and $72^{\circ} \mathrm{C}$ for $1 \mathrm{~min} 45 \mathrm{~s}$, with a final extension step of $7 \mathrm{~min}$ at $72^{\circ} \mathrm{C}$. The PCR products were electrophoresed on a $1.5 \%$ agarose gel containing $1 \times$ Tris-borate/EDTA electrophoresis buffer (TBE), and visualized by ethidium bromide staining.

\section{DNA sequencing}

The PCR products were concentrated and purified with a Microcon YM-100 unit (Millipore Bedford, MA, USA). Cycle sequencing of region $\mathrm{A}$ was done in a volume of $10 \mu \mathrm{l}$ containing $50-100 \mathrm{ng}$ of concentrated PCR product DNA, primer D4pos1 (sense), on a Thermocycler with the BigDye Terminator Cycle Sequencing Ready Reaction Kit (PE Biosystems, Foster City, CA, USA). The cycle sequencing
This region is responsible for the cell type-specific expression of the gene and contains transcription initiation sites located between -501 and -436 . The open box indicates the negative modulator. The open arrowheads indicate the orientation of two sets of oligonucleotide primers, D4pos3/D4pos4 and D4neg3/D4neg4 for amplification of regions $\mathrm{A}$ and $\mathrm{B}$, respectively

protocol was as recommended by the manufacturer, except for an annealing temperature of $52.5^{\circ} \mathrm{C}$ and performance of 32 cycles.

Cycle sequencing of region $\mathrm{B}$ was done in a volume of $10 \mu$ l containing $50-100 \mathrm{ng}$ of concentrated PCR product DNA, primer D4neg3 (sense) or D4neg4 (antisense) on the Thermocycler with the Kit. The cycle sequencing protocol was as recommended by the manufacturer except for an annealing temperature $57^{\circ} \mathrm{C}$ and performance of 32 cycles. Sequences were analyzed and collected on a Model ABI Prism 377 DNA Sequencer (PE Biosystems, Foster City, CA, USA).

\section{Polymorphisms and allele frequencies}

We determined the nucleotide sequence of regions $\mathrm{A}$ and $\mathrm{B}$ of the DRD4 gene from 80 and 67 unrelated Japanese individuals, respectively. Nine novel polymorphic sites and one known site $(-521 \mathrm{C}>\mathrm{T})$ (Okuyama et al. 1999) were identified in the upstream region of the $D R D 4$ gene. The genotype and allele frequencies of $-809 \mathrm{G}>\mathrm{A},-768 \mathrm{G}>$ $\mathrm{A},-616 \mathrm{C}>\mathrm{G},-603 \mathrm{~T}>\mathrm{del},-602 \mathrm{G}>\mathrm{del},-600 \mathrm{G}>\mathrm{C}$, $-521 \mathrm{C}>\mathrm{T},-376 \mathrm{C}>\mathrm{T},-291 \mathrm{C}>\mathrm{T}$ in 67 and $-128 \mathrm{G}>\mathrm{T}$ in 80 Japanese are summarized in Table 1 . The allele frequency of $-521 \mathrm{C}>\mathrm{T}$ was the same as that reported by Okuyama et al. (1999).

Six of these polymorphic sites were also recognized as the following restriction fragment length polymorphisms 
Table 1. Genotype and allele frequencies in the upstream region of the $D R D 4$ gene

\begin{tabular}{llllll}
\hline Position & Genotype frequency & & \multicolumn{2}{l}{ Allele frequency } \\
\hline \multirow{2}{*}{128} & $\mathrm{G} / \mathrm{G}$ & $\mathrm{G} / \mathrm{T}$ & $\mathrm{T} / \mathrm{T}$ & $\mathrm{G}$ & $\mathrm{T}$ \\
& 0.975 & 0.000 & 0.025 & 0.975 & 0.025 \\
-291 & $\mathrm{C} / \mathrm{C}$ & $\mathrm{C} / \mathrm{T}$ & $\mathrm{T} / \mathrm{T}$ & $\mathrm{C}$ & $\mathrm{T}$ \\
& 0.761 & 0.164 & 0.075 & 0.843 & 0.157 \\
-376 & $\mathrm{C} / \mathrm{C}$ & $\mathrm{C} / \mathrm{T}$ & $\mathrm{T} / \mathrm{T}$ & $\mathrm{C}$ & $\mathrm{T}$ \\
& 0.836 & 0.134 & 0.030 & 0.903 & 0.097 \\
-521 & $\mathrm{C} / \mathrm{C}$ & $\mathrm{C} / \mathrm{T}$ & $\mathrm{T} / \mathrm{T}$ & $\mathrm{C}$ & $\mathrm{T}$ \\
& 0.179 & 0.463 & 0.358 & 0.410 & 0.590 \\
-600 & $\mathrm{G} / \mathrm{G}$ & $\mathrm{G} / \mathrm{C}$ & $\mathrm{C} / \mathrm{C}$ & $\mathrm{G}$ & $\mathrm{C}$ \\
& 0.910 & 0.060 & 0.030 & 0.940 & 0.060 \\
-602 & $\mathrm{G} / \mathrm{G}$ & $\mathrm{G} / \mathrm{del}$ & $\mathrm{del} / \mathrm{del}$ & $\mathrm{G}$ & $\mathrm{del}$ \\
& 0.463 & 0.224 & 0.313 & 0.575 & 0.425 \\
-603 & $\mathrm{~T} / \mathrm{T}$ & $\mathrm{T} / \mathrm{del}$ & $\mathrm{del} / \mathrm{del}$ & $\mathrm{T}$ & $\mathrm{del}$ \\
& 0.358 & 0.194 & 0.448 & 0.455 & 0.545 \\
-616 & $\mathrm{C} / \mathrm{C}$ & $\mathrm{C} / \mathrm{G}$ & $\mathrm{G} / \mathrm{G}$ & $\mathrm{C}$ & $\mathrm{G}$ \\
& 0.149 & 0.269 & 0.582 & 0.284 & 0.716 \\
-768 & $\mathrm{G} / \mathrm{G}$ & $\mathrm{G} / \mathrm{A}$ & $\mathrm{A} / \mathrm{A}$ & $\mathrm{G}$ & $\mathrm{A}$ \\
& 0.970 & 0.015 & 0.015 & 0.978 & 0.022 \\
-809 & $\mathrm{G} / \mathrm{G}$ & $\mathrm{G} / \mathrm{A}$ & $\mathrm{A} / \mathrm{A}$ & $\mathrm{G}$ & $\mathrm{A}$ \\
& 0.582 & 0.254 & 0.164 & 0.709 & 0.291 \\
\hline
\end{tabular}

(RFLPs):

- SacII RFLP: PCR products of region A were digested with SacII. Allele G-128 was digested in five fragments, of $344,232,102,47$, and $39 \mathrm{bp}$, respectively, whereas allele $\mathrm{T}-128$ was digested in four fragments, of 446, 232, 47, and $39 \mathrm{bp}$.

- AvaI RFLP: PCR products of region B were digested with $A v a \mathrm{I}$. Allele C-291 was digested in four fragments, of 403, 149, 137, and $103 \mathrm{bp}$, whereas allele T-291 was digested in three fragments, of 403, 240, and 149bp.

- RsaI RFLP: PCR products of region $\mathrm{B}$ were digested with RsaI. Allele T-376 was digested in two fragments, of 571 and $221 \mathrm{bp}$, whereas allele C-376 was uncut.

- BssH II RFLP: PCR products of region B were digested with BssH II. Allele C-521 was digested in three fragments, of 426, 184, and $182 \mathrm{bp}$, whereas allele T-521 was digested in two fragments, of 608 and $184 \mathrm{bp}$.

- AvaII RFLP: PCR products of region B were digested with AvaII. Allele G-616 was digested in five fragments, of $334,178,146,127$, and $7 \mathrm{bp}$, whereas allele C-616 was digested in four fragments, of 512, 146, 127, and $7 \mathrm{bp}$.

- NarI RFLP: PCR products of region B were digested
A

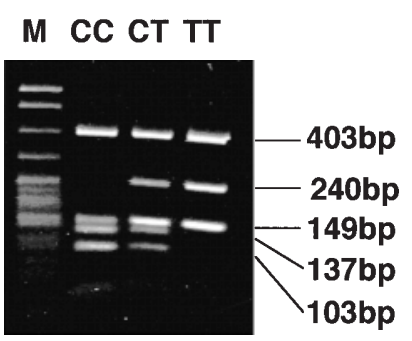

B

M GG GA AA

Fig. 2A, B. Genotyping of the $-291 \mathrm{C}>\mathrm{T}$ and $-768 \mathrm{G}>\mathrm{A}$ polymorphisms. Digestion products were electrophoresed on a $3.0 \%$ agarose gel and visualized by ethidium bromide staining. A Genotyping of the $-291 \mathrm{C}>\mathrm{T}$ polymorphism by digestion of region B PCR products with AvaI. Lane CC, Homozygote for the $\mathrm{C}$ allele; lane $C T$, heterozygote; lane $T T$, homozygote for the T allele; lane $M$, DNA molecular weight marker pBR322 DNA - MspI digests (New England BioLabs, Beverly, MA, USA). B Genotyping of the $-768 \mathrm{G}>$ A polymorphism by digestion of region B PCR products with NarI. Lane GG, Homozygote for the $\mathrm{G}$ allele; lane $G A$, heterozygote; lane $A A$, homozygote for the A allele; lane $M$, as in $\mathbf{A}$

with NarI. Allele G-768 was digested in three fragments, of 499, 179, and 114bp, whereas allele A-768 was digested in two fragments, of 678 and $114 \mathrm{bp}$.

As representatives, the genotyping of $-291 \mathrm{C}>\mathrm{T}$ and $-768 \mathrm{G}>\mathrm{A}$ polymorphisms based on RFLPs is shown in Fig. 2A, B.

\section{References}

Kamakura S, Iwaki A, Matsumoto M, Fukumaki Y (1997) Cloning and characterization of the 5'-flanking region of the human dopamine D4 receptor gene. Biochem Biophys Res Commun 235:321-326

Lahiri DK, Nurnberger JI, Jr (1991) A rapid non-enzymatic method for the preparation of HMW DNA from blood for RFLP studies. Nucleic Acids Res 19:5444

Okuyama Y, Ishiguro H, Toru M, Arinami T (1999) A genetic polymorphism in the promoter region of DRD4 associated with expression and schizophrenia. Biochem Biophys Res Commun 258:292-295

Seeman P, Guan H-C, Van Tol HHM (1993) Dopamine D4 receptors elevated in schizophrenia. Nature 365:441-445

Stefanis NC, Bresnick JN, Kerwin RW, Schofield WN, McAllister G (1998) Elevation of D4 dopamine receptor mRNA in postmortem schizophrenic brain. Brain Res Mol Brain Res 53:112-119 